\title{
EXPERIENCE OF FUNCTIONAL RECONSTRUCTION \\ OF SHOPPING CENTERS OF FRANCE, JAPAN, USA, CHINA, GERMANY AND UKRAINE IN THE ERA OF DIGITAL TECHNOLOGIES
}

\section{ДОСВІД ФУНКЦІОНАЛЬНОЇ ПЕРЕБУДОВИ ТОРГОВИХ ЦЕНТРІВ ФРАНЦЇ̈, ЯПОНІЇ, США, КИТАЮ, НІМЕЧЧИНИ ТА УКРАЇНИ В ЕПОХУ ЦИФРОВИХ ТЕХНОЛОГІЙ}

\section{Hanna Zhikhareva-Tolstik ${ }^{1}$ Victoria Datsenko ${ }^{2}$}

DOI: https://doi.org/10.30525/978-9934-26-021-6-17

Abstract. Shopping center operators still have ample opportunities to innovate, transform functionally, benefit and remain relevant to $21^{\text {st }}$ century buyers. This is especially true for emerging markets, where income growth, increased discretionary spending, and urbanization have created opportunities for social and commercial «directions.» To improve the experience of both buyers and tenants, operators must constantly offer a variety of new, fast-delivery services and technology-based products. This will require the use of flexible approaches to testing new products, events and services, and then rapid adaptation based on feedback. Shopping center operators will also need to extend this more flexible operating model to their tenants, facilitating close coordination. For all this, operators need people who understand flexible design, process redesign, as well as IT architecture and infrastructure.

Achieving this new way of working and maintaining customer focus requires cultural shift operators from shopping center operators. Operators

\footnotetext{
${ }^{1}$ Graduate Student of the Department of State, Local and Corporate Finance;

Lecturer at the Department of International Economic Relations,

Regional Studies and Tourism, University of Customs and Finance, Ukraine; media expert Media Scientific Hub

ORCID: https://orcid.org/0000-0003-0322-2859

${ }^{2} \mathrm{PhD}$ in Economics, Associate Professor of Entrepreneurship,

Marketing and Business Economics, University of Customs and Finance, Ukraine;

Media Scientific Hub business analyst

ORCID: https://orcid.org/0000-0002-4670-6848
}

(C) Hanna Zhikhareva-Tolstik, Victoria Datsenko 
who have long been accustomed to long development cycles and low risk tolerance will need to adopt a mindset based on testing and training in which all employees become accustomed to feeling constantly failing and accepting failures as a necessary harbinger of success. This study examines a number of areas in which retailers should focus their efforts. Namely, rethinking leases, creating new revenue streams and additional services, using technology to increase the value of shopping centers and demand for modern opportunities.

In addition, this study conducted a survey of visitors to shopping and entertainment centers and determined the average frequency of visits. As an example, the authors of the study propose to consider the seven most creative models of functional restructuring and reconception of shopping and entertainment centers in France, Japan, USA, China, Germany and Ukraine.

\section{Introduction}

Дослідження світових тенденцій трансформування торгових центрів вказує на те, що в 2020 році спостерігаються здебільше напівзакриті магазини, що радіють натовпу, порожні автостоянки і банкрутства роздрібних торговців. Очевидно, що це важкі часи для торгових центрів і великих роздрібних мереж, які служать їх якорем. Дійсно, надлишкова пропозиція продукту і зростання електронної комерції стискають прибутковість та маржу, і клієнти вимагають унікального і персоналізованого досвіду, а не одне і те ж кожен раз для всіх. Можно подумати, що цифрова ера - це подія на рівні вимирання торгових центрів. Але звісно, це не так - у операторів торгових центрів як і раніше $\epsilon$ широкі можливості вводити нововведення, функціонально трансформуватись, отримувати вигоду і залишатися актуальними для покупців 21 століття. Це особливо вірно по відношенню до ринків, що розвиваються, де зростання доходів, збільшення дискреційних витрат і урбанізація створили можливості для соціальних і комерційних «напрямків». Як зазначила McKinsey в недавній статті, торгові центри майбутнього будуть не стільки робити покупки в магазинах, скільки надавати людям новий особистий досвід, який вони не можуть отримати на своїх смартфонах, - то, що деякі називають роздрібною торгівлею.

Провідні оператори торгово-розважальних центрів (далі - ТРЦ) уже почали перетворювати свої об'єкти в місця призначення, які виглядають, відчуваються і працюють зовсім інакше, ніж їхні попе- 
редники. У Китаї торгові центри вже відводять від 30 до 40 відсотків своєї площі під продукти харчування і напої. Деякі девелопери, такі як Wanda Commercial Properties, що об'єднують торговельну, розважальну і житлову нерухомість в єдиний великий комплекс, відводять до 50 відсотків своєї площі громадському пространству.

У Сполучених Штатах оператори доглядають за несподіваними орендарями, такими як Зал слави жінок Мічигану, який недавно переïхав в торговий центр Meridian Mall в Мічигані. Інші розглядають зміни зонування, які дозволять розмістити медичні кабінети або підприємства легкої промисловості.

Проте, навіть самі інноваційні оператори стикаються з проблемами економіки і рентабельності, пов'язаними з усіма цими змінами. Торгові центри з великою кількістю громадських місць, як правило, мають більш низьке використання площ, ніж традиційні торговельні центри, і відхід від випробуваного поєднання високооплачуваних торгових орендарів і провідних категорій розваг призводить до зниження доходів торгових центрів.

\section{2. Основні аспекти функціональної перебудови ТРЦ}

Грунтуючись на нашому досвіді роботи 3 операторами торгових центрів по всьому світу, ми вважаємо, що торговельні центри все ще можуть процвітати. Але для цього оператори повинні зосередити свої зусилля на чотирьох областях:

1. Переосмислення договорів оренди.

Традиційна модель справляння орендної плати з роздрібних орендарів, заснована виключно на їх продажах, не дозволить операторам отримати повну вартість від роздрібних продавців. Компанії повинні бути готові кинути виклик минулого практиці і заглянути вперед до нових моделей лізингу. У міру того як торгові центри інвестують в нові функції і пам'ятки, які збільшують відвідуваність, вони можуть досліджувати нові способи структурування фінансових угод з орендарями роздрібної торгівлі. Ми бачимо дві основні можливості, які можуть бути прийняті на додаток до існуючих механізмів отримання доходів, а не обов' язково замість них:

Плата, заснована на відвідуваності: орендарі платять в залежності від трафіку, який надходить в їх магазини або рухається по території 
торгового центру, де вони розташовані. Ця модель дозволяс операторам торгових центрів отримувати вигоду з зростаючої тенденції клі$є н т і в$, що приходять в магазини, щоб помацати і обмацати товари, але здійснюють покупки онлайн.

Розподіл доходів в Інтернеті: при ще більш прямому використанні поведінки «переглядайте офлайн, робіть покупки в Інтернеті» орендарі сплачують частину онлайн-продажів свого бренду, які відбуваються в межах географії торгового центру, зазвичай відображається відповідно до поштовими індексами. Деякі провідні ритейлери вже застосовують цей підхід до своїх продавцям.

2. Створення нових потоків доходів і додаткових послуг.

Щоб домогтися фінансового успіху в цю нову епоху, торговим центрам необхідно творчо підходити до використання своїх активів. Власники торгових центрів можуть продавати орендарям доступ до фізичної нерухомості для зберігання інвентарю, наприклад, оскільки в майбутньому багато магазинів, ймовірно, будуть менше і не зможуть вмістити складські приміщення. Оператори також могли надавати орендарям логістичні послуги. Інші нові джерела доходу можуть включати використання відкритих просторів торгового центру для спливаючих магазинів, тимчасових виставкових залів та інших заходів. Роздрібні продавці можуть платити за це за кожен трафік. Цифрові фасади, холи і атріуми також пропонують можливість гнучкого розміщення реклами. Нарешті, технології дають операторам торгових центрів величезний потенціал для упаковки і продажу даних про покупців своїм орендарям.

3. Використання технологій для збільшення вартості торгових центрів.

Цифрові технології являють собою загрозу для торгових центрів, тому що вони дозволяють покупцям робити покупки в Інтернеті. Але в той же час технології відкривають значні можливості операторам, які знають, як ними користуватися.

Інформація про покупців: використовуючи додатки, безкоштовний $\mathrm{Wi}-\mathrm{Fi}$, дані про торгові точки і камери відеоспостереження, оператори торгових центрів можуть краще зрозуміти, хто саме робить покупки в їхніх готелях і які купівельні звички і уподобання цих споживачів. Наприклад, аналітика Wi-Fi може виявити, які веб-сайти відвідують 
покупці, тим самим даючи уявлення про те, на що люди дивляться, подорожуючи по певного району торгового центру. Торговий центр Катррі в Гельсінкі, Фінляндія, за допомогою маяків для аналізу моделей пішохідного руху дізнався, що покупці збираються в обідній час, а не після роботи, як передбачалося раніше.

Всі ці дані також можна аналізувати, щоб отримати цінні відомості для орендарів, які хочуть поліпшити асортимент своєї продукції, вітрини, стратегії ціноутворення або рекламні акції. Розширена аналітика також може дозволити операторам оптимізувати набір орендарів і умови оренди. Визначаючи, які сегменти клієнтів, ймовірно, будуть робити покупки в наступний раз і для яких продуктів, аналітика може прогнозувати продуктивність орендарів і майбутню поведінку покупців.

Омніканальность. Торгові центри мають величезний потенціал для використання цифрових технологій для значного поліпшення купівельного досвіду і купівельного досвіду. Покупці хочуть безперешкодного і безпроблемної взаємодії між онлайн та офлайн, 3 невеликим розходженням між двома каналами. Це може означати покупку в Інтернеті і отримання в магазині або в центральних «залах для прийому замовлень», покупку в Інтернеті і повернення в магазини, отримання покупок на будинок і використовувалася програма торгового центру для здійснення покупок в торгових центрах, що вперше розробила Westfield. в деяких торгових центрах. Для забезпечення такого роду омніканальності потрібно, щоб оператори торгових центрів і роздрібні продавці оновлювали свої операції, щоб серверні системи могли поглинати і аналізувати дані, що надходять 3 інтерфейсних програм.

Технології також можуть бути використані для поліпшення загального враження відвідувачів від торгового центру. Мобільні додатки можуть пропонувати персональні рекомендації та рекламні акції, планування маршруту, цифрову навігацію і бронювання різних послуг, включаючи попереднє замовлення їжі, щоб клієнти знаходили їжу готової після прибуття.

4. Попит на сучасні можливості.

До сих пір оператори торгових центрів вважали себе керуючими капіталомістким бізнесом в сфері нерухомості і наймали відповідно. 


\section{3. Навички, які необхідні менеджерам ТРЦ у XXI столітті}

Сьогодні, коли торгові центри розробляють додатки, реалізують омніканальние стратегії і витягують інформацію з величезних обсягів даних про клієнтів, будуть потрібні люди з трьома новими наборами навичок:

- Зустрічі з мілленіаламі в місцях, де вони роблять покупки: формуючи майбутнє торгових центрів. Аналітика: 3 даними, які є такою великою частиною майбутнього для операторів торгових центрів, компаніям буде потрібно найняти безліч нових аналітиків даних, таких як інженери по обробці даних, які будуть організовувати, очищати і зберігати дані про клієнтів, а також фахівців з даними, які будуть створювати алгоритми для аналізу даних і вилучення інформації. Оператори торгових центрів також захочуть, щоб хтось на високому рівні в організації, наприклад, директор за даними, контролював, розставляв пріоритети і захищав управління даними. Нарешті, є «перекладачі», які сидять між керівниками бізнесу і технічним персоналом, полегшуючи спілкування і перетворюючи бізнес-потреби в алгоритмічні вимоги.

- Досвід роботи з клієнтами: Тепер, коли оператори торгових центрів будуть більш безпосередньо спілкуватися з покупцями, знання в області дизайнерського мислення, клієнтського досвіду і навіть поведінкової психології ставатимуть все більш важливими для проектування і експлуатації торгових центрів. Дубайський девелопер Маджид Аль Футтайм, наприклад, замовив нейробиологические дослідження, щоб зрозуміти, як свідома і несвідома активність мозку впливає на емоційну реакцію людей на події в сфері нерухомості. Торгові центри також захочуть створити інструменти і додатки, які дозволять їм задовольнити всі сегменти потреб і запитів покупців таким чином, щоб зробити процес покупок безпроблемним, приємним та незабутнім. Наприклад, лояльні покупці торгових центрів, які приїжджають в короткі поїздки, повинні мати можливість отримати безкоштовну парковку транспортних засобів персоналом.

- Необхідні як фахівці-практики дизайн-мислення, які проводять поглиблені дослідження, орієнтовані на емпатію 3 використанням етнографічних досліджень і інших якісних методів, так і дизайнери клієнтського досвіду, які створюють комплексний клієнтський досвід на основі результатів досліджень і відгуків. 
Щодо оперативної роботи торгових центрів: щоб поліпшити враження як покупців, так і орендарів, оператори повинні постійно пропонувати безліч нових, швидко доставляються послуг і продуктів, заснованих на технологіях. Це зажадає використання гнучких підходів до тестування нових продуктів, подій і послуг, а потім швидкої адаптації на основі відгуків. Операторам торгових центрів також необхідно буде поширити цю більш гнучку операційну модель на своїх орендарів, полегшуючи тісну координацію. Наприклад, для управління залами збору і порталами орендарів електронної комерції торговельні центри повинні будуть підключатися до внутрішніх систем логістики та інвентаризації орендарів. Для всього цього операторам потрібні люди, котрі розуміються на гнучкій розробці, редизайн процесів, а також IT-архітектурі та інфраструктурі.

Досягнення цього нового способу роботи і збереження орієнтації на клієнта зажадає від операторів торгових центрів провести культурний зрушення. Оператори, які давно звикли до тривалих циклів розробки і низької толерантності до ризику, повинні будуть прийняти образ мислення, заснований на тестуванні і навчанні, при якому всі співробітники звикнуть до відчуття постійного збою і прийняття невдач як необхідного передвісника успіху.

Керівництву необхідно буде взяти на себе ініціативу в формулюванні цього бачення, управлінні великою кількістю спільних команд і рольовому моделюванні цифрового поведінки таким чином, щоб переконати в необхідності глибоких змін.

Немає сумнівів в тому, що оператори торгових центрів стикаються 3 непростими умовами. Але ті, хто готовий відмовитися від старих моделей і побудувати більш динамічні і актуальні напрямки, зможуть створювати прибуткові торгові центри, які сьогоднішні покупці майже не дізнаються [1].

\section{4. Досвід функціональної перебудови ТРЦ у світі}

Розглянемо досвід трансформації ТРЦ у провідних країнах світу на прикладі семи найіноваційніших молів. Футуристичних ідей про те, як будуть виглядати майбутні торговельні центри, вистачає. У гонитві за увагу споживача будівельникам моллов доводиться бути все витонченішими. MarketMedia вивчив фішки останніх світових проектів. 
Один $з$ найбільших світових власників торгових центрів Westfield, представляючи громадськості своє бачення торгових центрів майбутнього, запропонував влаштовувати там кімнати тиші для відпочинку, прокладати річки, через які відвідувачі зможуть потрапляти всередину на човнах, а також встановлювати розумні туалети, що видають інформацію, які продукти вам необхідні . Звичайно, велика частина нових ТРК поки продовжує будуватися за традиційними схемами, світ змінюється так швидко, що, можливо, проекти, від яких сьогодні зносить дах, стануть нормою вже завтра. Або навіть раніше!

1. Гольф на даху. Досвід Франції. На дахах торгових центрів уже давно влаштовують парковки, зелені зони і навіть висаджують городи. Компанія Ceetrus сім’ї Мюлье (власники Auchan, Leroy Merlin i Decathlon), отримавши право реконструкції одного з семи вокзалів Парижа - Gare du Nord, - вирішила піти далі і розташувати там відкриті спортивні майданчики, поле для гольфу і стежку для пробіжок довжиною 1 км. За останніми екологічним стандартам на даху також

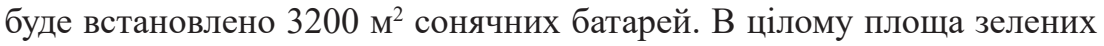

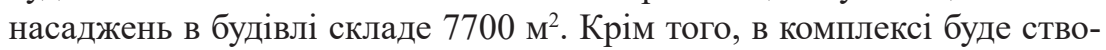

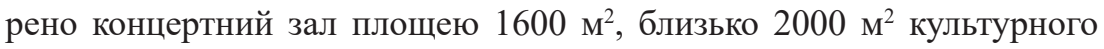
простору і ще близько $5000 \mathrm{~m}^{2}$ займе зона коворкінгу.

Всього, згідно з проектом, після всіх перетворень площа найбільшого вокзалу Свропи повинна буде збільшитися з нинішніх 36 тис. До 110 тис. м² (комерційних приміщень - 10 тис. до 50 тис. м²), обсяг інвестицій оцінюється в 600 млн євро. Завершити його планується до 2024 року.

2. Високе мистецтво. Досвід Японії. Найбільший виробник товарів класу lux LVMH відкрив в Токіо торговий центр Ginza 6, спільний проект з японської Mori Building Company. Крім зеленого даху і розкішних інтер'єрів організатори вирішили влаштовувати там регулярні мистецькі виставки (благо компанія Mori Building володіє ще й власним музеєм сучасного мистецтва). Так, наприклад, в честь відкриття була влаштована виставка яеі Кусама, однією з найдорожчих сучасних художників. Крім того, власники Ginza 6, в якому більше 240 бутиків, включаючи 10 брендів LVMH, пообіцяли влаштовувати в торговому центрі виступу японського театру Но.

3. Азіатський шик. Досвід Великої Британії. Не тільки європейські компанії активно виходять на азіатський ринок, спостерігається 
і зворотний ефект - східна культура, товари, мода і кухня стають все більш цікаві західним країнам. У Лондоні в 2015 році відкрився перший спеціалізований азіатський торговий центр - The East Shopping Centre. У ньому близько 35 бутиків, включаючи магазини національних весільних нарядів, а також 17 традиційних азіатських крамничок souk. Власники комплексу сподіваються залучати на європейський ринок нові азіатські бренди. Єдино, варто враховувати, що знаходиться ТРК в районі з великою кількістю вихідців з Південної Азії, тобто багато в чому оріснтований все-таки на них.

4. Інтерактив. Досвід Китаю. До літаючих дронів, які допомагають вам нести покупки, ще не дійшло, але багато провідні світові компанії вже готові вводити нові технології шопінгу, яких вже створено більш ніж достатньо. У квітні минулого року Alibaba group відкрила свій перший власний торговий центр, який став втіленням об'єднання онлайну і офлайна. У ньому п'ять поверхів, територія забудови 40 тис. м $^{2}$. Побудований в ультрасучасному стилі ТК More Mall в місті Ханчжоу, де розташована штаб-квартира компанії, оснащений різними інтерактивними технологіями: смарт-дзеркалами для тестування макіяжу, віртуальними кімнатами для підгонки - загалом, всім тим, що Alibaba представляла в своєму експериментальному офлайн магазин New Retail Interactive Store в одному з діючих ТК в Ханчжоу.

5. Імітація стріт-ритейлу. Досвід США. Вище ми говорили про бачення майбутнього торгових центрів від компанії Westfield, а тепер можна подивитися, що вона реально робить сама в одному зі своїх найбільших ТК Westfield Valley Fair в Силіконовій долині. В даний момент там повним ходом йде реставрація вартістю більше \$ 1 млрд. Дивно, але на ці гроші компанія вирішила річки не прокладати, але додала в проект підсвічені фонтани, пальми, оливкові дерева і відкриту терасу з 10 ресторанами під відкритим небом. Компанія також вирішила максимально наблизитися до ефекту вулиць і перемішати магазини, ресторани і розважальні центри, відмовившись від їх традиційного поділу по поверхах. У центрі алей будуть зони відпочинку, збільшиться обсяг відкритого простору. Все буде влаштовано таким чином, щоб покупець сам не розумів, як опинився в магазині. Крім того, буде збільшена азіатська експозиція.

6. Велике село. Досвід Франції. В імітації стріт-ритейлу можна зайти досить далеко. Ще один мегапроект групи Auchan спільно з китай- 
ськими інвесторами - це будівництво міста-супутника Парижа Europa City. Вирішивши створити там гігантську торговельну зону, проект зіткнувся з активним протестом місцевих фермерів, після чого компанія пообіцяла, що не будуватиме «вульгарний мультиплекс» і замість одного найвищої будівлі побудує відкриту малоповерхову торгову галерею. При цьому магазини будуть оточені парками розваг і розбавлені культурними просторами. Всього площа забудови складе близько 80 га, площа торгових зон - 150 тис. м². Почати будівництво планується в 2020 році, і до цього моменту автори повинні будуть доопрацювати концепт. До слова, приклади, коли замість одного багатоповерхового торгового центру будувалася ціла прогулочно-торгова зона, що імітує маленькі магазини, були і раніше - так, наприклад, виглядає подібний простір в Bercy. Побудована BercyVillage була ще на початку 2000-х.

7. Затишок дерева. Досвід Німеччини. Ну і останній торговий центр, на якому хотілося б зупинитися, - це Berlin Bikini. Він був відкритий після реновації в 2014 році, проте відрізняється від більшості перерахованих вище, і тому захотілося поговорити про нього окремо. Його площа - всього 17 тис. м², тому творці вирішили зробити в ньому ставку на затишок і часту зміну торгової експозиції. Замість ультрасучасного дизайну - дерев'яне оздоблення, лаундж-зон з диванами милі подушечки на вікнах. 3 тераси на даху з садом площею 7 тис. м² відкривається вид на зоопарк. Орендарі Berlin Bikini - переважно невеликі магазини, а частина модулів призначена для торгівлі рор-uр тимчасових торгових точок, які відкриваються на кілька тижнів або місяців. Чим не свіжа ідея в епоху гламуру і блиску [2].

\section{5. Категорійний менеджмент у розрізі позиціонування ТРЦ}

Розглянемо категорійний менеджмент, дослідження його аналітики в сфері рітейлу стосовно позиціонування та керування торгово-розважальними комплексами. Однією з причин, чому науковці зацікавились керуванням асортиментом на рівні продуктових лінійок, або товарних категорій полягала в тому, що аналіз на рівні окремих SKU було визнано занадто складним. Наприклад, знання того, як конкретні найменування товарів реагують на ті, або інші промо-заходи не мало безпосередньої практичної цінності для рітейлеру. Можно сказати, що в деякому сенсі асортимент жив своїм життям, а магазин своїм. 
Наприклад дослідження Р. Френка та У. Массі (1970) показало, що в магазинах, які продають більшу кількість окремого товару останній мав досить високу еластичність викладки (вище 0,6$)$ у той час як в магазинах невеликими об'ємами продажу даного товару його чутливість до площі викладки була значно нижче (близько 0,03 ). На основі такої інформації досить складно приймати стратегічні рішення по асортименту, особливо якщо він складається тисяч SKU із різним рівнем еластичності. Таким чином, на думку багатьох, одиницею керування асортиментом, на якій бажано зосередитись рітейлерам повинна бути не найменування товару, а категорія.

Одним із перших кроків у цій сфері стало переусвідомлення розуміння товарної категорії (Category Management Best Practices Report 1993). Ідея полягала в тому, що їх визначення повинно бути основане на процесі прийняття рішень покупцями, а не на звичному для рітейлу розподілу, здебільш співпадаючім промисловій специфікації. Наприклад категорія закусок відтепер могла включати солодощі, чіпси, фрукти та морозиво. Таким чином, у відповідності до нового підходу, усі товари які розглядаються покупцем як заміняючі один одного відносились до однієї категорії [3].

Клієнтами торгового центру, з одного боку, є його відвідувачі, а 3 іншого - орендарі, від успішної діяльності яких залежить дохід власника торгової нерухомості. Це породжує багатогранність і складність завдань керуючої структури ТРЦ: необхідно аналізувати ринок комерційної нерухомості та тенденції його розвитку, стежити за змінами в роздрібній торгівлі, сфері послуг і розваг, враховувати розвиток форматів, конкуренцію і розподіл сил між гравцями в кожній області.

Найважливішим завданням маркетингового дослідження виступає оцінка поведінки споживачів на ринку, їх особистісних, культурних, соціальних і психологічних характеристик.

В якості методу дослідження було використане опитування споживачів, орієнтований на масових респондентів різної кваліфікації і компетенції. Метою опитування став збір інформації для визначення причин, чому покупці іншим торговим точкам воліють ТРЦ, а також переваг при виборі торгового центру. Сегментація споживачів за частотою відвідин ТРЦ відображена на рисунку 1: 


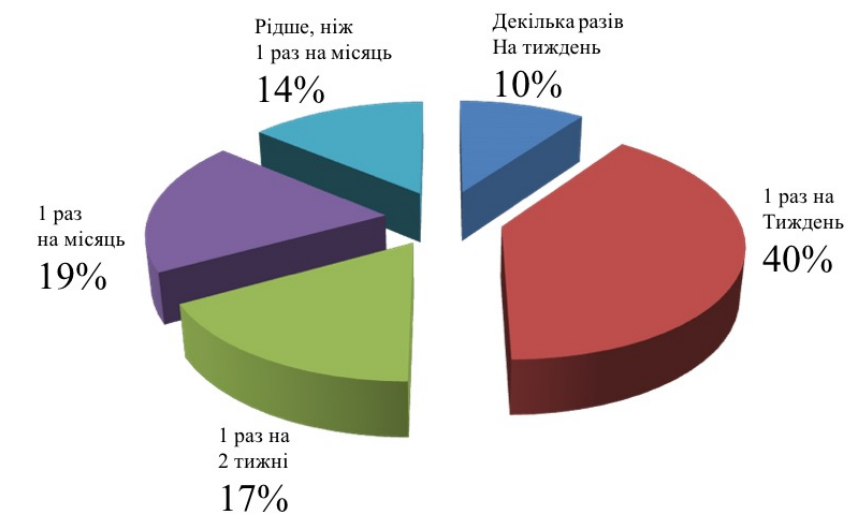

\section{Рис. 1. Сегментація споживачів за частотою відвідин торгово-розважальних центрів України}

Опитувалися люди різних вікових категорій, основною частку склала молодь у віці 16-21 року. Більшість опитаних мають середньомісячний дохід 5-7 тис. грн. на 1 члена в сім’ї. Всього лише на 2 відсотки менше опитаних мають дохід 10-20 тис. грн.

Як показало опитування в Україні, більшість респондентів відвідує ТРЦ 1 раз в тиждень. Чим частіше споживачі відвідують торгові центри, тим більша ймовірність, що буде здійснена покупка. Аналітика трансформації торгово-роважальних центрів в Україні вказує на те, що в окремих випадках прибутковість ТРЦ в регіонах показують позитивну динаміку. Деякі власники, які помітили зміну попиту, своєчасно прийшли до реконцепції і підлаштувалися під нові вимоги ринку, сьогодні розвиваються в рамках нової перебудованої стратегії. На прибутковості ТРЦ також зіграли і зміни курсу валюти. Якщо ми будемо розглядати прибутковість в гривні, то можна відзначити позитивну тенденцію. Але сьогодні гривня просідає щодо долара - це важливий момент, оскільки економічна база залежить більшою мірою від експортних операцій, які здійснюються у валюті.

Час відвідування торгового центру в середньому по Україні скоротився на 30-40 відсотків. Наприклад, якщо говорити про великий ТРЦ в столиці, то в середньому людина проводила там 4-4,5 години, сьогодні вона проводить там 3 години. Знову ж варто розуміти, що 
в окремих випадках відвідуваність зросла - це може бути результат маркетингових акцій в торговому центрі або більш вимогливий вибір покупця, але при цьому не збільшується число покупок. Ще одна причина для збільшення відвідуваності - проведення дозвілля. Люди приходять не для здійснення покупок, а для простого проведення часу. В українських ритейлерів помилки зустрічаються частіше, ніж у зарубіжних. Як правило, останні не економлять на дослідженнях цільової аудиторії. Групу Inditex (іспанська корпорація 35 тис. магазинів по всьому світу, володіє брендами Massimo Dutti, Bershka, Oysho, Pull and Bear, Stradivarius, Zara, Tempe, Uterque, Lefties) вважається однією 3 найбільш вимогливих компаній на українському ринку, яким необхідні якісні орендні площі та проведення ремонту відповідно до їх дизайнерських проектів. В цей же час багато їхніх українських колег не готові вкладати значні кошти в дизайн та оздоблення приміщень, економлячи на матеріалах або обладнанні. Зарубіжні рітейлери опрацьовують питання глибше, оскільки споживачі не пробачають помилок: конкуренція на ринку висока і знайти заміну досить легко. До того ж західні і американські ритейлери тривалий період часу розвиваються в умовах стабільної економіки, що дає їм здатність, з одного боку, будувати прогнози щодо майбутніх перевагам споживачів, з іншого - веде до жорсткої конкурентної боротьби між рітейлерами за споживача. Споживач вибирає рітейлера. Споживач голосує грошима за ті чи інші магазини. Рітейлер, який хоче, щоб його споживач не змінював йому, залишався 3 ним, повертався за покупками до нього знову і знову, змушений працювати над багатьма аспектами свого бізнесу, але в першу чергу - над оформленням, викладкою, обслуговуванням. Клієнтоорієнтованість - це завжди довгострокова стратегія, це не тактика. В Україні і країнах пострадянського простору ситуація інша - 1991 року ми переживаємо вже четверту кризу. Стадії рецесії і процвітання мають занадто короткий часовий період, що перешкоджає стабільному розвитку. Тому у бізнесменів, в тому числі ритейлерів, немає можливості створення довгострокової стратегії, основна мета полягає в тому, щоб вичавити по максимуму сьогодні.

Кожні п'ять років торговому комплексу варто міняти концепцію, але правильні об'єкти займаються реконцепцію практично 
постійно. Наприклад, «Каравани» раз в два-два 3 половиною роки змінюють частину орендарів. I чинить абсолютно правильно краще раз в два роки вкласти кілька засобів в зміни, ніж чекати до останнього, потім затівати великі зміни, які спричинять за собою великі витрати, а головне - можливість втратити частину аудиторії. У нинішніх умовах великий вплив інтернет-торгівлі, багато необхідних товарів можна купити онлайн. Сучасні торговельні об'єкти крім функції шопінгу повинні нести в собі і додаткові функції - розважальні або соціальні. Важливо, щоб торговий комплекс відповідав вимогам ринку і споживача.

Орендні ставки по Україні знизилися на 15-40 відсотків, але в окремих випадках власники ТЦ мають можливість зберегти їх на колишньому рівні. Наприклад, якщо торговий центр користується популярністю серед відвідувачів або ТЦ-монополіст, так як на ринку міста немає конкуренції. Хоча обсяги введення нових площ в даному сегменті значно знизилися, бізнес-центри продовжують будувати. В незалежності від кризи бізнес продовжує розвиватися, підлаштовуючись під нові ринкові умови, формуючи попит на орендні площі [4].

\section{6. Використання розширеної аналітики. Тренд менеджменту ТРЦ}

Зокрема, розширена аналітика може зробити революцію практично у всіх сферах бізнесу торгових центрів. На жаль, багато операторів торгових центрів відстають від своїх орендарів в тому, що стосується розширеної аналітики. Одне з часто цитованих пояснень полягає в тому, що торгові центри звичайно не взаємодіяли безпосередньо зі споживачами, тому у них не так багато даних про споживачів для аналізу. Але ми виявили, що торгові центри вже мають доступ до значних обсягів даних, включаючи дані про поведінку покупців, продажу орендарів і ефективності категорій. Чого у них зазвичай немає, так це аналітичних навичок та інструментів для аналізу даних. Більшість операторів торгових центрів як і раніше приймають рішення, грунтуючись на традиціях, досвіді або інтуїції, тим самим залишаючи цінність на столі.

Тим не менше, кілька далекоглядних торгових центрів лідирують в області розширеної аналітики. Вони використовують яка дозволяє 
і прогнозну аналітику - вбудовану в зручні для користувача інструменти з потужними можливостями візуалізації даних - для прийняття більш розумних бізнес-рішень. У цій статті ми розповімо, як торгові центри використовують розширену аналітику в особливо важливої частини свого бізнесу: управлінні доходами. Вони визначають оптимальне поєднання магазинів, розуміють і планують сусідство магазинів, яке стимулює зростання споживчих витрат і більш тривалі відвідування торгових центрів, а також проводять більш інформовані переговори про оренду з орендарями. Це окупається: торгові центри, які використовують ці інструменти, збільшили свої доходи від оренди на двозначні відсотки.

\section{7. Підбір оптимального поєднання магазинів}

Більшість операторів торгових центрів вирішують, яких орендарів здавати в оренду і які приміщення в торговому центрі будуть займати кожен магазин. Деякі торгові центри мають базову сегментацію орендарів за категоріями, але їм не вистачає систематичного і аналітичного підходу до розстановки пріоритетів, пошуку та залучення орендарів. У них немає заснованого на даних способу відповіді на важливі питання, наприклад: які типи магазинів найкраще привертають споживачів, які живуть або працюють в зоні обслуговування торгового центру? Привертають чи мої якірні магазини відвідуваність і продажі в мій торговий центр? Які орендарі є несподіваними «двигунами витрат» (тобто орендарями, які стимулюють перехресну конверсію i, таким чином, створюють цінність, незважаючи на свої низькі показники продажів)? Які комбінації магазинів або категорій дають найвищі сукупні продажі в торгових центрах?

Власник торгового центру в Азії використовує інструмент розширеної аналітики, який обробляє дані про продажі і дані на рівні транзакцій, щоб виявити типові пішохідні маршрути в торговому центрі і шаблони перехресного перетворення між категоріями. Інструмент дозволяє кількісно оцінити, як кожен магазин впливає на загальні споживчі витрати в торговому центрі. Іншими словами, він досліджує ефективність кожного магазину як механізму витрат: він показує, наскільки присутність конкретного орендаря збільшує або зменшує продажу в інших магазинах, і чи будуть споживачі робити покупки в певних гру- 
пах магазинів під час одного відвідування торгового центру. Наприклад, компанія дізналася, що в її якірному магазині, де багато одягу, $\epsilon$ тенденція до зниження продажів в найближчих магазинах одягу, в той же час збільшуючи продажі в довколишніх магазинах аксесуарів і косметики. Інструмент також може кількісно оцінити «ефект ореолу» магазину на оптові та онлайн-продажу орендаря.

Таке розуміння важливо для оптимізації вибору і розміщення орендарів. Вивчаючи результати роботи інструменту, компанія може визначити магазини, розмір яких, можливо, буде потрібно змінити, перемістити, переоцінити, видалити або отримати маркетингову підтримку. Наприклад, орендар з низькою продуктивністю (тобто з низькими продажами на квадратний фут в порівнянні з іншою частиною торгового центру), але з високою продуктивністю перехресного перетворення, потенційно може бути змінений в розмірі або переміщений в меншу одиницю.

\section{8. Відповідність орендарів локаціях}

Коли група з оренди розглядає договори оренди, термін дії яких закінчується в наступному кварталі або році, їй слід вивчити сукупність потенційних орендарів, які можуть заповнити трубопровід: поточні орендарі, яким може бути краще зайняти інше приміщення в торговому центрі, орендарі, що входять до складу компанії . інші торгові центри, але не в цьому, і будь-які потенційні нові орендарі, які висловили зацікавленість в оренді приміщення.

Власники торгових центрів іноді реконструюють окремі «території» або частини торгового центру, присвячені виключно певним категоріям товарів. Ці проекти реконструкції надають можливість перемістити орендарів в різні приміщення в торговому центрі. Оцінка всіх можливих комбінацій і перестановок - складна вправа, що вимагає мощі просунутої аналітики. Нові інструменти - назвемо їх інструментами «правильний орендар, правильне розташування» (RTRL) - дозволяють оцінити багатоканальні продажу кожного орендаря і орендну плату, яку він повинен платити, в кожної потенційної комбінації орендарів і одиниць. (Зверніть увагу, що при визначенні орендної плати орендаря основною метою оператора торгового центру має бути не максимізація власного доходу від оренди, а, ско- 
ріше, максимізація сукупних продажів орендарів торгового центру. Це може здатися нелогічним, оскільки продажі орендарів безпосередньо не відображаються Вплив на чистий прибуток для оператора торгового центру. Але оскільки співвідношення витрат на заповнення кожного арендатора знижується, приміщення в торговому центрі стають більш здоровими і стійкими, що допомагає торговому центру залишатися життєздатним).

Вищезазначена компанія використовувала інструмент RTRL, щоб з'ясувати, які десять 3 її потенційних орендарів повинні замінити десять поточних орендарів, термін оренди яких закінчувався, і які конкретні одиниці в торговому центрі повинні зайняти нові орендарі. Інструмент показав, що 3 новою групою з десяти орендарів торговий центр може принести додатковий дохід від продажів на 115 мільйонів доларів в порівнянні з попереднім роком, а також додаткові 5 мільйонів доларів доходу від оренди.

Дані про продажі і продуктивності складають основу інструменту RTRL; його прогнози будуть настільки гарні, наскільки хороша наявна у нього інформація як про поточні, так і про потенційних орендарів. Власник торгового центру повинен зібрати достатньо надійних даних - в ідеалі не тільки про багатоканальних продажах, але і про витрати на розміщення, - щоб інструмент міг диференціювати потенційну продуктивність орендаря в блоці А в порівнянні 3 блоком В. Якщо власник торгового центру не має даних про передбачуване орендаря, йому слід ретельно вибирати еталони зі свого поточного портфеля магазинів.

Iнструмент RTRL також повинен вміти враховувати бізнес-обмеження. Наприклад, якщо в торговому центрі є ділянки, інструмент не повинен призначати роздрібного продавця іграшок доступним підрозділом на ділянці одягу або фуд-корті. Крім того, власник торгового центру повинен вказати мінімальну або максимальну частку категорії - наприклад, одяг високого класу на рівні 10 відсотків від загальної площі торгового центру, недорога електроніка на рівні 3 відсотків і так далее. Без розумних бізнес-обмежень інструмент неминуче буде рекомендувати розміщувати високопродуктивні категорії (наприклад, розкішні аксесуари або побутову електроніку) в невиправдано великих магазинах. 


\section{9. Установка діапазону цін для кожної оренди}

Однією з основних проблем для власників торгових центрів у всьому світі є визначення орендної плати для кожного орендаря. У типовому торговому центрі немає чітких процесів або загального розуміння всередині організації того, як встановлювати цілі оренди для кожного орендаря; команди з управління активами та лізингу, наприклад, часто досягають різних цілей. Загальнодоступних галузевих тестів по країнам або категоріям не існує. Наше власне дослідження показує, що дохід від оренди торгового центру, виражений як відсоток від загального обсягу продажів орендарями, варіюється в широких межах - від 5 відсотків для торгового центру в Бразилії до 25 відсотків для торгового центру в Австралії.

Теоретично орендна плата за одиницю в торговому центрі залежить від чотирьох змінних: типу та місця розташування торгового центру, кількості і якості пішохідного потоку, характеристик (включаючи розмір і конфігурацію) приміщення і продуктивності продажів. марка або категорія, в якій буде розміщуватися даний пристрій. Однак на практиці все інакше. Ми виявили, що менеджери з оренди житла засновують орендну плату за квартиру на особистому знанні орендаря («Я знаю його, він не заплатить більше х доларів»), минулого практиці («Давайте збільшимо орендну плату на 2 відсотки в цьому році, наприклад ми робимо щороку»), або поєднання інтуїції і ділової хватки.

Чітке уявлення про загальну економіці орендарів і на рівні одиниць в поєднанні з інструментом ціноутворення з розширеною аналітикою допомагає власникові торгового центру в Азії встановлювати більш точні цілі оренди. Компанія проводить ретельний аналіз економіки кожного зі своїх орендарів, вивчаючи не тільки обсяг продажів на одиницю, але також витрати на розміщення і прибуток. Потім він використовує інструмент ціноутворення, який розбиває чотири раніше перерахованих змінних приблизно на 25 подпараметров, таких як близькість об'єкта до входу в торговий центр і цінове позиціонування бренду. Використовуючи многовариантную регресію, інструмент встановлює ціновий діапазон (або «зону можливого згоди») для кожного поточного або потенційного орендаря. Таким чином, розрахунок створення вартості на рівні одиниці - і визначення розрахункової 
вартості оренди (ERV) одиниці для кожного орендаря - стає набагато більш суворим процесом.

Розширена аналітика дозволяє компанії управляти і покращувати не тільки свої короткострокові результати, але і їх стан в довгостроковій перспективі. Інструмент ERV однієї компанії ясно показав, що неефективні орендарі торгового центру платили орендну плату, яка була непропорційно вище, ніж в середньому по торговому центру, що фактично субсидіювала інших орендарів. Це була нестійка ситуація: рано чи пізно переплачують орендарі представляли б значний ризик виникнення вакансії, особливо якщо б вони були зосереджені в рамках одного циклу оренди або на території торгового центру. Інструмент також показав, що власник торгового центру може більш наполегливо вести переговори зі своїми більш ефективними орендарями. У таких ситуаціях впровадження інструменту і дії на підставі таких аналітичних даних можуть принести до 5 відсотків прибутку до вирахування відсотків, податків, зносу і амортизації в рік.

\section{9. Висновки}

Розглянувши дані даного дослідження, можно впевнено стверджувати, що операторам рітейл-середи потрібно бути готовими до швидких змін та до реагування на нові технологічні виклики миттєво.

Щоб домогтися успіху в епоху цифрових технологій, операторам торгових центрів необхідно прищепити культуру прийняття рішень на основі фактів у всій організації. Крім впровадження інструментів розширеної аналітики, їм слід вкладати кошти в збір більшої кількості цінних даних, які будуть використовуватися в їх бізнес-рішеннях. Наприклад, вони можуть розгортати нові технології (такі як маяки, деталізований Wi-Fi i камери розпізнавання осіб) для збору поведінкових даних. Вони можуть запускати програми лояльності в торговому центрі, щоб збирати дані про окремі транзакції і аналізувати шлях кліента.по всій екосистемі торгового центру. Вони також можуть налагоджувати партнерські відносини з орендарями - наприклад, шляхом переговорів про кращою орендній платі в обмін на спільне використання даних. Збройні надійними даними та передовими інструментами аналітики, торгові центри можуть відродити і революціонізувати не тільки ефективність власного бізнесу, а й решту галузі роздрібної торгівлі [1]. 


\section{Список літератури:}

1. Pranay Agarwal, Raffaele Breschi, Sandrine Devillard-Hoellinger. How the mall-business can reinvent itself for a digital age. Mckincey\&Company Marketing\&Sales (electronic journal), November 30/2017, Article. Retrieved from: https:/www.mckinsey.com/business-functions/marketing-and-sales/our-insights/ how-the-mall-business-can-reinvent-itself (accessed 05 December 2020).

2. Йенс Нордфальт. Ryteil-marketing \& Практики и исследования. Москва : Альпина Паблишер, 2018.

3. Марат Манасян. «Среднее время посещения торгового центра сократилось на 30-40\%. Было 4,5 часа стало 3». БізнесOnline [BusinessOnline] (electronic journal), vol. 01/2016. Retrieved from: https://www.business-gazeta.ru/ article/299551 (accessed 01 December 2020).

4. Ismail Bel-Bachir, Sandrine Devillard, Alex Sawaya, Ivana Valachovicova. Boosting mall revenues through advanced analytics. Mckincey\&Company Marketing\&Sales (electronic journal), vol. 01/2019. Retrieved from: https://www.mckinsey.com/industries/retail/our-insights/boosting-mall-revenues-through-advanced-analytics\# (accessed 11 December 2020).

\section{References:}

1. Pranay Agarwal, Raffaele Breschi, Sandrine Devillard-Hoellinger. How the mall-business can reinvent itself for a digital age. Mckincey\&Company Marketing\&Sales (electronic journal), November 30/2017, Article. Retrieved from: https://www.mckinsey.com/business-functions/marketing-and-sales/our-insights/ how-the-mall-business-can-reinvent-itself (accessed 05 December 2020).

2. Jens Nordfalt (2018) Ryteil-marketing \& Practiki i issledovaniya [Retail marketing. Practice and research]. Moscow: Alpina Publisher. (in Russian)

3. Marat Manasyan (2016) "The average time of visiting the shopping center has decreased by $30-40 \%$. It was 4.5 hours." BusinessOnline [BusinessOnline] (electronic journal), vol. 01/2016, Art. Retrieved from: https://www.business-gazeta.ru/ article/299551 (accessed 01 December 2020).

4. Ismail Bel-Bachir, Sandrine Devillard, Alex Sawaya, Ivana Valachovicova. Boosting mall revenues through advanced analytics. Mckincey\&Company Marketing\&Sales (electronic journal), vol. 01/2019. Retrieved from: https://www.mckinsey.com/industries/retail/our-insights/boosting-mall-revenues-through-advanced-analytics\# (accessed 11 December 2020). 